\title{
REVIEW
}

\section{Instrumental analysis of some anti-ulcer drugs in different matrices}

\author{
Samar S. Elbaramawi ${ }^{1} \quad$ Mohamed E. El-Sadek $^{1} \quad$ Mohamed M. Baraka $^{1} \quad$ Lobna M. \\ Abdel-Aziz ${ }^{1}$ Mahmoud M. Sebaiy ${ }^{1^{*}}$
}

\begin{abstract}
In this literature review, we will introduce most reported methods that have been developed for determination of certain anti-ulcer drugs such as Ranitidine hydrochloride, Famotidine, Omeprazole, Pantoprazole sodium, Tinidazole and Doxycycline hyclate in their pure form, combined form with other drugs, combined form with degradation products, and in biological samples.
\end{abstract}

Keywords: Ranitidine hydrochloride, Famotidine, Omeprazole, Pantoprazole sodium, Tinidazole, Doxycycline hyclate

\section{Introduction}

Peptic ulcers are localized erosions of the mucous membranes of the stomach and duodenum. The pain associated with ulcers is caused by irritation of exposed surfaces by the stomach acids. Anti-ulcer therapy has been a huge money spinner for the pharmaceutical industry with drugs such as Cimetidine, Ranitidine $\left(\mathrm{H}_{2}\right.$-receptor antagonists) and Omeprazole (proton pump inhibitor). None of these drugs were available until the 1960s, however, and it is perhaps hard for us now to appreciate how dangerous ulcers could be before that. In the early 1960s, the conventional treatment was to try to neutralize gastric acid in the stomach by administering antacids. These were bases, such as sodium bicarbonate or calcium carbonate. The dose levels required for neutralization were large and caused unpleasant side effects. Relief was only temporary. The first effective anti-ulcer agents were the $\mathrm{H}_{2}$ histamine antagonists which appeared in 1960s. These were followed in 1980s by the proton pump inhibitors (PPIs). The discovery of $H$. pylori then led to the use of antibacterial agents in ani-ulcer therapy. The current approach for treating ulcers caused by $H$. pylori is to use combination of drugs, which includes a PPI, and two antimicrobials, such as Tinidazole and Doxycycline. ${ }^{[1]}$ As such, This literature review will shed the light about all reported methods that

\footnotetext{
Received: Oct. 5, 2020 Accepted: Nov. 10, 2020 Published: Nov. 17, 2020

* Correspondence to: Mahmoud M. Sebaiy, Department of Medicinal Chemistry, Faculty of Pharmacy, Zagazig University, Zagazig 44519, Egypt; Email: mmsebai@zu.edu.eg

${ }^{1}$ Department of Medicinal Chemistry, Faculty of Pharmacy, Zagazig University, Zagazig 44519, Egypt

Citation: Elbaramawi SS, El-Sadek ME, Baraka MM, et al. Instrumental analysis of some anti-ulcer drugs in different matrices. Chem Rep, 2020, 2(1): 156-172.

Copyright: $\odot 2020$ Mahmoud M. Sebaiy, et al. This is an open access article distributed under the terms of the Creative Commons Attribution License, which permits unrestricted use, distribution, and reproduction in any medium, provided the original author and source are credited.
}

have been developed for determination of drugs used for peptic ulcer such as Ranitidine hydrochloride, Famotidine, Omeprazole, Pantoprazole sodium, Tinidazole and Doxycycline hyclate in their pure form, combined form with other drugs, combined form with degradation products, and in biological samples such as liquid chromatography, spectrophotometry, spectroflourimetry, electrophoresis, etc.

\section{Ranitidine hydrochloride}<smiles></smiles>

Chemical name:

$N$-[2-[[[5-[(Dimethylamino) methyl]-2-furanyl] methyl] thio] ethyl]- $N$ '-methyl-2-nitro-1, 1-ethenediamine, hydrochloride. ${ }^{[2]}$

Molecular formula: $\mathrm{C}_{13} \mathrm{H}_{22} \mathrm{~N}_{4} \mathrm{O}_{3}$ S.HCl

Molecular weight: 350.87

Physical properties:

Appearance: Off- white to pale yellow crystalline powder

Solubility: Freely soluble in water and sparingly soluble in alcohol

Melting point: About $70^{\circ} \mathrm{C}$

\section{Pharmacological action:}

Ranitidine is a histamine $\mathrm{H}_{2}$-receptor antagonist and inhibits the actions of histamine mediated by $\mathrm{H}_{2}$-receptors such as gastric acid secretion and pepsin output. It is used where inhibition of gastric acid secretion may be beneficial as in peptic ulcer disease including stress ulceration, gastroesophageal reflux disease and selected cases 
of persistent dyspepsia. ${ }^{[3]}$

\section{Methods of determination:}

Ranitidine hydrochloride is official in B.P. $2011^{[4]}$ where it was determined by titration and the end point was determined potentiometrically, and in U.S.P. XXXII ${ }^{[2]}$ using HPLC method.

\section{Spectrophotometric methods:}

Perez-Ruiz et al.,$^{[5]}$ described a spectrophotometric method for determination of trace amounts of ranitidine through liquid-liquid extraction using bromothymol blue.

Spectrophotometric stability indicating method was developed for quantitative determination of ranitidine hydrochloride in the presence of its oxidative derivatives in both raw material and in pharmaceutical formulations. Hydrogen peroxide was used to enhance the formation of S-oxide compounds (oxidative derivatives). Direct zero order, first derivative and the second derivative of the ratio spectra had been carried out for the determination of the drug. ${ }^{[6]}$

Spectrophotometric method was developed for determination of ranitidine through its oxidation by a known excess of bromate in acid medium and in the presence of excess bromide followed by estimation of surplus oxidant by reacting with either indigo carmine or metanil yellow and measuring the absorbance at $\lambda_{\max } 610$ or $530 \mathrm{~nm} .{ }^{[7]}$

Potassium iodate and 2,7-dichlorofluorescein were used for spectrophotometric determination of ranitidine. The absorbance of the coloured solution was measured at $\lambda_{\max } 520 \mathrm{~nm}^{[8]}$

Another spectrophotometric method was developed depending on addition of fixed amount of perchloric acidcrystal violet mixture to different amounts of ranitidine and measuring the absorbance spectrophotometrically at $\lambda_{\max } 570 \mathrm{~nm}^{\left[{ }^{[9]}\right.}$

Two spectrophotometric methods were developed for determination of ranitidine $\mathrm{HCl}$. The first method was a kinetic spectrophotometric method based on the catalytic effect of ranitidine on the reaction between sodium azide and iodine and measuring the decrease in iodine absorbance at $\lambda_{\max } \max 348 \mathrm{~nm}$. In the second method; complexes were formed between (o-phenanthroline) iron (II) and tris (bipyridyl) iron (II) measuring the absorbances at $\lambda_{\max } 512 \mathrm{~nm} .^{[10]}$

Potassium dichromate was used as oxidimetric reagent in spectrophotometric determination of ranitidine in pharmaceuticals. ${ }^{[11]}$

$\mathrm{N}$-bromosuccinimide (NBS) was used as an analytical reagent for the determination of ranitidine $\mathrm{HCl}$. The method involved the reaction of ranitidine $\mathrm{HCl}$ with NBS and then the excess NBS was estimated by its reaction with $\mathrm{p}$-aminophenol to give a violet colored product that was measured at $\lambda_{\max } 552 \mathrm{~nm} .^{[12]}$

Another sensitive spectrophotometric method was described for the determination of ranitidine $\mathrm{HCl}$ in pharmaceuticals. This method was based on the formation of red colored condensation product with pdimethylaminobenzaldehyde followed by measurement of absorbance at $\lambda_{\max } 503 \mathrm{~nm} .{ }^{[13]}$

Ceric ammonium sulphate and two dyes; malachite green and crystal violet were used for spectrophotometrically determination of ranitidine $\mathrm{HCl}$ at $\lambda_{\max } 615$ and $582 \mathrm{~nm}$ respectively. ${ }^{[14]}$

Ranitidine gives colored ion-pair complexes with bromocresol purple, methyl orange, eriochrome cyanine and alizaraine red $\mathrm{S}$ with maximum absorption peaks at $\lambda_{\max } 408,420,330$ and $326 \mathrm{~nm}$ respectively. ${ }^{[15]}$

\section{Spectroflourimetric methods:}

Spectrofluorimetric method was adopted for the analysis of ranitidine depending on its reaction with 1,4- Benzoquinone reagent at $\mathrm{pH}$ 5.6. The resulting condensation product exhibited fluorescence at $\lambda_{e m} 665 \mathrm{~nm}$ when excited at $\lambda_{\text {exc }} 290 \mathrm{~nm} .{ }^{[16]}$

Ulu $\mathrm{S}$ and Cakar $\mathrm{M}^{[17]}$ developed a sensitive spectrofluorimetric method for the determination of ranitidine hydrochloride. This method was based on derivatization of ranitidine with 4-fluoro-7-nitrofurazan (NBD-F). The method was linear over the range of 40-1200 ng/ml.

\section{Chromatographic methods:}

Chromatographic methods have been widely applied for determination of ranitidine in pure form, in pharmaceutical formulations or in biological fluids. These methods include HPLC method for the determination of ranitidine in commercial products. As a column of Inertsil ${ }^{\circledR}$ ODS-2 was used and 0.04 $\mathrm{M}$ aqueous sodium dihydrogen phosphate: acetonitrile: methanol: triethylamine at a proportion of (345: 20: 35: $0.7, \mathrm{v} / \mathrm{v} / \mathrm{v} / \mathrm{v}$ ) was the selected mobile phase. The detection wavelength was set at 230 nm. ${ }^{[18]}$

Also, there are HPTLC methods which were used for determination of ranitidine $\mathrm{HCl}$ in pharmaceutical preparations. The separation was performed on silica precoated plates using the U.S.P. XXIII mobile phase; toluene: methanol: diethylamine (9: 1: 1, v/v/v). The samples were applied on a HPTLC plate automatically. Quantification was done by densitometry at in situ UV absorption at $320 \mathrm{~nm} .{ }^{[19]}$ Another HPTLC method was described for the determination of ranitidine in the presence of its sulfoxide derivatives. The latter method involved quantitative densitometric evaluation of mixture of the drug and its derivatives after separation by high-performance 
thin-layer chromatography on silica gel plates with ethyl acetate: methanol: $20 \%$ ammonia $(10: 2: 2, \mathrm{v} / \mathrm{v} / \mathrm{v})$ as the mobile phase. ${ }^{[20]}$

Ranitidine was assayed in plasma samples by HPLC using a Lichrocrat Lichrospher ${ }^{\circledR}$ RP-select B column. The mobile phase consisted of $0.2 \%$ triethylamine, 0.04 M phosphate buffer (pH 6.8) and 14\% acetonitrile. ${ }^{[21]}$

Simultaneous determination of ranitidine and metronidazole in human plasma was presented. The plasma protein was precipitated by perchloric acid. The resultant supernatant was analyzed on Shimpak $\mathrm{C}_{18}$ column using phosphate buffer ( $\mathrm{pH} 3.5)$ : acetonitrile $(90: 10, \mathrm{v} / \mathrm{v})$ as a mobile phase and detection wavelength at $315 \mathrm{~nm} .{ }^{\text {[22] }}$

HPLC method was developed for the simultaneous determination of ranitidine, methylparaben and Propylparaben as preservatives in oral liquids. The chromatographic separation was achieved by HPLC using a mixture of $0.5 \mathrm{M}$ ammonium acetate, acetonitrile and methanol as the mobile phase, a Nucleosil $\mathrm{C}_{18}$ column and UV detection at $254 \mathrm{~nm} \cdot{ }^{[23]}$

Simultaneous determination of ranitidine was performed by Arayn et al., ${ }^{[24]}$ on a Purospher Star $\mathrm{RP}_{18}$ endcapped column using a mobile phase of methanol: water: triethylamine $(20: 80: 0.05, \mathrm{v} / \mathrm{v} / \mathrm{v})$ whose $\mathrm{pH}$ was adjusted to 3.0 with phosphoric acid (85\%). The detection was set at $229 \mathrm{~nm}$.

Stability-indicating RP-HPLC method was developed for the determination of ranitidine in the presence of its impurities, forced degradation products and placebo substances such as saccharide and parabens. Chromatographic separation was achieved on ACE $\mathrm{C}_{18}$ column using gradient mixture of two solvents. The first solvent is mixture of phosphate buffer ( $\mathrm{pH}$ 6.5) and acetonitrile (98: $2, \mathrm{v} / \mathrm{v})$. The second one is mixture of water and acetonotrile $(5: 95, \mathrm{v} / \mathrm{v})$. Ultraviolet detection was performed at $230 \mathrm{~nm} \cdot{ }^{[25]}$

Another RP-HPLC method with fluorescence detection was described for the determination of ranitidine in human plasma. The method was based on the reaction of ranitidine with 4-fluoro-7-nitrobenzo-2-oxa-1, 3-diazole (NBD-F) forming a yellow colored fluorescent duct. The separation was achieved on $\mathrm{C}_{18}$ column using methanolwater $(60: 40, v / v)$ as a mobile phase. Fluorescence detection was used at the excitation and emission of 458 and $521 \mathrm{~nm}$, respectively. ${ }^{[26]}$

Gas chromatography method was developed for the determination of ranitidine in pharmaceutical preparations and serum using methylglyoxal as derivatizing agent. ${ }^{[27]}$

\section{Miscellaneous methods:}

Stability-indicating spectrodensitometric method was applied for the determination of ranitidine $\mathrm{HCl}$ using linear and non-linear regression. ${ }^{[28]}$

A simple capillary zone electrophoresis method was described for the simultaneous determination of ranitidine. $^{[29]}$

Issa et al. ${ }^{[30]}$ presented ion-selective electrodes for potentiometric determination of ranitidine $\mathrm{HCl}$ applying batch and flow injection analysis techniques.

Based on the chemiluminescence intensity generated from the potassium ferricyanide $\left[\mathrm{K}_{(3)} \mathrm{Fe}(\mathrm{CN})_{(6)}\right]$ rhodamine $6 \mathrm{G}$ system in sodium hydroxide medium, a flow-injection chemiluminescence (FI-CL) method had been developed, validated and applied for the determination of ranitidine $\mathrm{HCl}^{[31]}$

Ranitidine $\mathrm{HCl}$ was determined potentiometrically through construction of ion-selective electrodes. Two types of electrodes: carbon paste and screen printed electrodes were constructed based on the ion-pair formation during potentiometric titration of ranitidine with tetraphenyl borate. ${ }^{[32]}$

Chang et al. ${ }^{[33]}$ developed a selective fluorescence quenching method for the determination of ranitidine in tablets and biological fluids.

A sensitive potentiometric method was described for the determination of ranitidine using modified carbon paste and insitu carbon paste electrodes. ${ }^{[34]}$

\section{Famotidine}<smiles>NC(N)=Nc1nc(CSCC/C(N)=N/S(N)(=O)=O)cs1</smiles>

\section{Chemical name:}

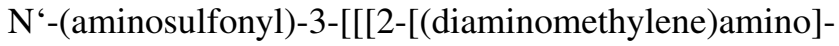
4-thiazolyl] methyl]thio]- Propanimidamide

Molecular formula: $\mathrm{C}_{8} \mathrm{H}_{15} \mathrm{~N}_{7} \mathrm{O}_{2} \mathrm{~S}_{3}$

Molecular weight: 337.45

Physical properties:

Appearance: White to pale yellow crystalline powder

Solubility: Freely soluble in glacial acetic acid, slightly soluble in methanol and very slightly soluble in water

Melting point: About $163^{\circ} \mathrm{C}$

\section{Pharmacological action:}

Famotidine is a histamine $\mathrm{H}_{2}$-receptor antagonist that inhibits the actions of histamine mediated by $\mathrm{H}_{2}$-receptors such as gastric acid secretion and pepsin output. It is used in treatment of peptic ulcer disease including stress ulceration, gastroesophageal reflux disease and selected cases of persistent dyspepsia. ${ }^{[3]}$

\section{Methods of determination:}


Famotidine is official and can be determined in both B.P. $2011^{[4]}$ and U.S.P. XXXII ${ }^{[2]}$ by non aqueous titration and the end point is determined potentiometrically.

\section{Spectrophotometric methods:}

Charge transfer complexes were formed between famotidine and chloranilic acid ${ }^{[35]}$ and $7,7,8,8-$ tetracyanoquinodimethane; ${ }^{[36]}$ measured spectrophotometrically at $\lambda_{\max } 525 \mathrm{~nm}$ and $840 \mathrm{~nm}$, respectively.

Amin et al. ${ }^{[37]}$ described three methods for the spectrophotometric determination of famotidine. The first method was based on oxidation of the drug by $\mathrm{N}$ bromosuccinimide (NBS) and determination of the unreacted NBS by measuring the decrease in absorbance of Amaranth dye at $\lambda_{\max } 521 \mathrm{~nm}$. The other two methods involved addition of excess cerrric sulphate and determination of unreacted $\mathrm{Ce}$ (IV) by decrease the red color of chromotrope $2 \mathrm{R}$ at $\lambda_{\max } 528 \mathrm{~nm}$ or decrease the orange pink color of rhodamine $6 \mathrm{G}$ at $\lambda_{\max } 526 \mathrm{~nm}$.

A ternary complex was formed with famotidine, eosin and $\mathrm{Cu}$ (II) which was measured at $\lambda_{\max } 548 \mathrm{~nm}$. ${ }^{[38]}$

Another spectrophotometric method was developed for the determination of famotidine. The method was based on the interaction of ninhydrin with famotidine resulting in a blue colored product measured at $\lambda_{\max } 590 \mathrm{~nm} .^{\text {[39] }}$

Ayad et al.,${ }^{[40]}$ developed two spectrophotometric methods for the determination of famotidine. The methods were based on the oxidation of the drug with iron (III) in acidic medium. The liberated iron (II) reacted with 1,10- phenanthroline (method A) and the ferroin complex was measured at $\lambda_{\max } 510 \mathrm{~nm}$. Method B was based on the reaction of the liberated Fe (II) with 2,2- bipyridyl to form a stable colored complex with $\lambda_{\max }$ at $520 \mathrm{~nm}$.

Palladium (II) chloride was used to form a complex with famotidine which measured spectrophotometrically at $\lambda_{\max } 345 \mathrm{~nm}$. $^{[41]}$

A kinetic spectophotometric method for the determination of famotidine was described. The method was based on the oxidation of the drug with alkaline potassium permanganate and measuring the rate of change of absorbance at $\lambda_{\max } 610 \mathrm{~nm}^{\text {[42] }}$

Reddy et al.,${ }^{[43]}$ described a bromination method for famotidine using excess bromine in acidic medium. The developed yellow color was measured spectrophotometrically at $\lambda_{\max } 350 \mathrm{~nm}$.

Also famotidine was oxidized by cerium (IV) in presence of perchloric acid and subsequent measurement of excess Ce (IV) by its reaction with p- dimethylaminocinnamaldehyde to give a red colored product measured at $\lambda_{\max } 464$ nm. $^{[44]}$

Ion-pair complexes were formed between famotidine and four sulphonphthalein dyes; bromothymol blue, bro- mophenol blue, bromocresol purple and bromocresol green in dioxane or acetone medium. Complexes were measured at $\lambda_{\max } \max 410 \mathrm{~nm} .{ }^{\text {[45] }}$

Simultaneous spectrophotometric method was developed for the determination of famotidine and domperidone in combined tablet dosage form through using ratio spectra derivative and area under curve method. ${ }^{[46]}$

Araujo et al., ${ }^{[4]}$ developed two methods for the determination of famotidine in pharmaceutical preparations. The first method was based on the hydrolysis of famotidine with sodium hydroxide, assisted with microwave radiation. The produced sulphide was allowed to interact with N, N-diethyl-p-phenylendiamine oxalate and Fe (III) and measuring the blue colored product at $\lambda_{\max } 671$ $\mathrm{nm}$. The second method was based upon formation of ternary complex between the drug, lead (II) and eosin in presence of methylcellulose as a surfactant and measuring the absorbance at $\lambda_{\max } 541 \mathrm{~nm}$.

\section{Spectrofluorimetric methods:}

Spectrofluorimetric method was adopted for the analysis of famotidine depending on its reaction with 1,4 Benzoquinone reagent at $\mathrm{pH}$ 5.2. The resulting condensation product exhibited fluorescence at $\lambda_{e m} 665 \mathrm{~nm}$ when excited with $\lambda_{\text {exc }} 290 \mathrm{~nm} .^{[16]}$

Famotidine was determined spectrofluorimetrically in pharmaceutical preparations and biological fluids through ternary complex formation with some lanthanide ions. The relative fluorescence intensity of complexes measured at $\lambda_{e m} 580 \mathrm{~nm}$ after excitation with $\lambda_{\text {exc }} 290 \mathrm{~nm} .^{[48]}$

A stability indicating spectrofluorimetric method was developed for the determination of famotidine. It was based on the reaction of famotidine with 9, 10phenanthraquinone in alkaline medium to give a highly fluorescent derivative measured at $\lambda_{e m} 560 \mathrm{~nm}$ after excitation with $\lambda_{\text {exc }} 283 \mathrm{~nm}$. ${ }^{[4]}$

\section{Chromatographic methods:}

HPLC method was developed for the determination of famotidine in commercial products depending on using Inertsil ODS-2 column and mobile phase consisting of phosphate: acetonitrile: methanol: triethylamine (345: 20: 35: $0.7, \mathrm{v} / \mathrm{v} / \mathrm{v} / \mathrm{v})$. Detection wavelength was set at $230 \mathrm{~nm} .^{[18]}$ Another HPLC method was described for estimation of famotidine in human plasma and urine using $\mathrm{C}_{18}$ reversed phase column and water- saturated ethyl acetate as a mobile phase. Detection was carried out at wavelength $267 \mathrm{~nm} .^{[50]}$

Zhong et al., ${ }^{[51]}$ developed a normal phase chromatography method coupled with tandem mass spectrometry for the determination of famotidine in human plasma and urine. The chromatographic separation was accomplished 
by using BDS Hypersil silica column with a mobile phase of acetonitrile-water containing trifluoroacetic acid.

HPTLC method was described for the determination of famotidine in presence of its sulfoxide derivatives. The method involved quantitative densitometric evaluation of mixture of the drug and its derivatives after separation by high-performance thin-layer chromatography on silica gel plates with ethyl acetate: isopropanol: $20 \%$ ammonia $(9: 5: 4, \mathrm{v} / \mathrm{v} / \mathrm{v})$ as a mobile phase. ${ }^{[20]}$

RP-HPLC analysis of famotidine in human plasma was reported after solid phase extraction. ${ }^{[52]}$ Another RPHPLC methods were developed for the determination of famotidine in pharmaceutical products. ${ }^{[25,53,54]}$

A quantitative method using silica gel high performance thin layer chromatography (HPTLC) plates with fluorescent indicator, automated sample application, and ultraviolet (UV) absorption videodensitometry was developed for the determination of famotidine tablets. ${ }^{\text {[55] }}$

Reddy et al., ${ }^{[56]}$ developed a stability-indicating liquid chromatographic method for the simultaneous determination of ibuprofen and famotidine in combined pharmaceutical dosage form (tablets).The separation was achieved on Acquity UPLC $\mathrm{C}_{18}$ column with gradient elution. The mobile phase A was a mixture of acetate buffer ( $\mathrm{pH} 5.5)$ and methanol (85: $15, \mathrm{v} / \mathrm{v})$ while the proportion was $(25$ : 75 , v/v) for the mobile phase B. The detection wavelength was $260 \mathrm{~nm}$.

\section{Miscellaneous methods:}

A simple capillary zone electrophoresis method was described for the simultaneous determination of famotidine. ${ }^{[29]}$

Two potentiometric methods were developed for the determination of famotidine in pure form and in its tablet form. The first method was based on construction of plasticised ploy (vinyl chloride) matrix type famotidine ion-selective membrane electrode. In the second one, lead acetate was used for oxidation of thioether contained in famotidine. The titration was made in presence of catalytic quantities of potassium bromide. ${ }^{[57]}$

A flow injection kinetic spectrophotometric method was described for the determination of famotidine in pharmaceutical preparations. The method was based on a kinetic investigation of the oxidation reaction of the drug in alkaline potassium permanganate. ${ }^{[58]}$

Moreover, a flow-injection chemiluminescence (FI-CL) method based on the chemiluminescence intensity generated from the potassium ferricyanide $\left[\mathrm{K}_{(3)} \mathrm{Fe}(\mathrm{CN})_{(6)}\right]-$ rhodamine $6 \mathrm{G}$ system in sodium hydroxide medium; was developed, validated and applied for the determination of famotidine. ${ }^{[31]}$

Electrochemical behavior of famotidine had been stud- ied at composite polymer membrane working electrode. Cyclic voltammetric method was developed for the determination of drug in pharmaceutical formulation. ${ }^{[59]}$

\section{Omeprazole}

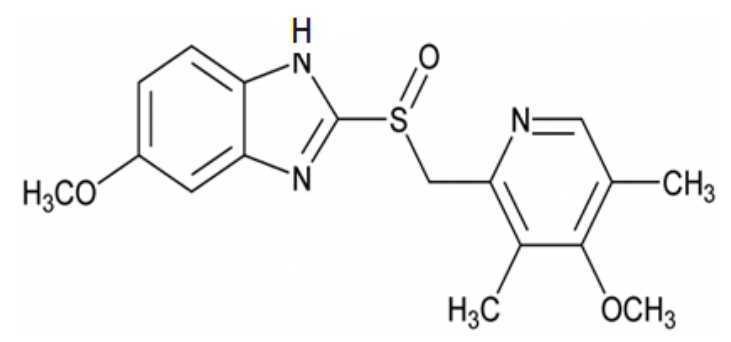

Chemical name:

5-Methoxy-2-[[(4-methoxy-3,5-dimethyl-2-pyridinyl) methyl] sulfinyl] benzimidazole

Molecular formula: $\mathrm{C}_{17} \mathrm{H}_{19} \mathrm{~N}_{3} \mathrm{O}_{3} \mathrm{~S}$

Molecular weight: 345.42

Physical properties:

Appearance: White to off-white crystalline powder

Solubility: Very slightly soluble in water, soluble in alcohol and dichloromethane

Melting point: $156^{\circ} \mathrm{C}$

\section{Pharmacological action:}

Omeprazole is a proton pump inhibitor, used in treatment of peptic ulcer disease and NSAID-associated ulceration, in gastro-esophageal reflux disease and the Zollinger-Ellison syndrome. ${ }^{[3]}$

\section{Methods of determination:}

Omeprazole is official in B.P. 2011 $1^{[4]}$ where it was determined by titration with standard solution of alkali hydroxide and determining the end-point potentiometrically and in U.S.P. XXXII ${ }^{[2]}$ using HPLC method.

\section{Spectrophotometric methods:}

Two stability-indicating spectrophotometric methods were described for the determination of omeprazole in the presence of its degradation products. The first method depended on use of first, second and third derivative spectrophotometry at 290, 320, $311 \mathrm{~nm}$, respectively. The second method was based on applying the charge transfer technique with chloranil and measuring the complex at $\lambda_{\max } 377 \mathrm{~nm}^{[60]}$

The compensation method and other chemometric methods (derivative, orthogonal function and difference spectrophotometry) had been applied to the direct determination of omeprazole in pharmaceutical preparations. ${ }^{[61]}$

Spectrophotometric procedures for the determination of omeprazole were developed. The procedures were based on the formation of chelates of the drug with different 
metal ions. The colored chelates of omeprazole in ethanol were determined at $\lambda_{\max } 411,339$ and $523 \mathrm{~nm}$ using iron (III), chromium (III) and cobalt (II), respectively. ${ }^{[62]}$

Karljikovic et al., ${ }^{[63]}$ applied the first order UVspectrophotometry using zero-crossing method for the determination of omeprazole and omeprazole sulphone.

Omeprazole was reacted with iron (III) and subsequent reacted with ferricyanide which yielded a prussion blue product with maximum absorption at $\lambda_{\max } 720 \mathrm{~nm} .^{[64]}$

Two spectrophotometric methods were developed for the determination of losartan potassium and omeprazole in single component pharmaceutical dosage forms. The methods were based on the formation of ion-pair complexes of the drug with bromocresol purple and bromophenol blue in acidic buffer solutions followed by their extraction in chloroform. ${ }^{[65]}$

Extractive spectrophotometric determination of omeprazole was developed using acidic dyes; bromophenol blue and orange $\mathrm{G}$ as ion-pairing agents in aqueous medium ( $\mathrm{pH} 7$ and 6 , respectively). The ion pair chromogen formed, which was extracted with chloroform, was measured quantitatively at $\lambda_{\max } 408 \mathrm{~nm}$ and $508 \mathrm{~nm}$, respectively. ${ }^{[66]}$

Mahmoud, A. M, ${ }^{[67]}$ developed a kinetic spectrophotometric method for determination of omeprazole. The method was based on charge-transfer complex, formed between iodine and 2,3-dichloro-5,6-dicyano-1,4benzoquinone (DDQ).

Two spectophotometric methods were developed for the simultaneous estimation of omeprazole and cinitapride in combined dosage form through simultaneous equation method and absorbance ratio method. ${ }^{[68]}$

Comparative study of spectrophotometric methods manipulating ratio spectra was developed for the determination of ternary complex of omeprazole, tinidazole and clarithromycin. ${ }^{[69]}$

Spectrophotometric method based on nucleophilic substitution reaction was developed for the determination of omeprazole. The method was based on the reaction of omeprazole with sodium 1,2-naphthoquinone-4sulphonate in alkaline medium and the absorbance was measured at $\lambda_{\max } 453 \mathrm{~nm} .{ }^{[70]}$

\section{Spectrofluorimetric methods:}

Indirect spectrofluorimetric determination of omeprazole by its quenching effect on the fluorescence of $\mathrm{Tb}^{3+}$ 1, 10 -phenanthroline complex in presence of bis (2ethylhexyl) sulfosuccinate sodium in capsule formulations was reported. The mixture was measured at $\lambda_{e m} 545$ $\mathrm{nm}$ using an excitation wavelength of $\lambda_{\text {exc }} 300 \mathrm{~nm}$. ${ }^{\text {[7] }}$

\section{Chromatographic methods:}

Different chromatographic techniques have been applied for the analysis of omeprazole. Omeprazole was determined by HPLC with coulometric detection using a porous carbon electrode. ${ }^{\text {[72] }}$

RP-HPLC method was developed for the quantitative determination of omeprazole in the presence of its acidinduced degradation products. The chromatographic analysis was achieved by using Nova-Pak $\mathrm{C}_{18}$ column and $0.05 \mathrm{M}$ potassium dihydrogen phosphate: methanol: acetonitrile (50: 30: 20, v/v/v) as a mobile phase. The detection was carried out at wavelength $208 \mathrm{~nm}^{\left[{ }^{[73]}\right.}$

Another RP-HPLC method was developed for quantification of omeprazole in delayed release tablets. The analysis was carried out using a $\mathrm{RP}-\mathrm{C}_{18}$ column with UV detection at $280 \mathrm{~nm}$. The mobile phase consisted of phosphate buffer (pH 7.4): acetonitrile (70:30, v/v). ${ }^{[74]}$

Raval et al., ${ }^{[75]}$ developed a HPTLC method for the determination of ondansetron in combination with omeprazole in solid dosage form. The method involved separation of components by TLC on a precoated silica gel using a mixture of dichloromethane: methanol (9: $1, \mathrm{v} / \mathrm{v})$ as a mobile phase. Detection of spots was carried out at 309 nm. Moreover Dedania et al., ${ }^{[76]}$ developed a RP-HPLC method for the simultaneous estimation of omeprazole and ondansetron in combined tablet dosage form. Chromatographic separation was achieved on RP-C ${ }_{18}$ column. The mobile phase was a combination of methanol: acetonitrile (90: 10, v/v). The detection was carried at 218 $\mathrm{nm}$.

RP-HPLC methods were described for determination of omeprazole in human plasma. Chromatographic separation was performed using gradient elution, on Zorbax $\mathrm{C}_{18}$ column. The mobile phase A was $22.0 \mathrm{mM}$ phosphate ( $\mathrm{pH} 6$ ), while the mobile phase B was composed of phosphate: acetonitrile: methanol (10: 80: 10, v/v/v) detection wavelength was set at $302 \mathrm{~nm}$. ${ }^{\text {[7] }}$

Another RP-HPLC method was developed for determination of omeprazole in human serum. As the mobile phase consisted of a mixture of $0.2 \mathrm{M}$ potassium dihydrogen phosphate buffer ( $\mathrm{pH}$ 7.2) and acetonitrile (70: 30, $\mathrm{v} / \mathrm{v}$ ), pumped through $\mathrm{C}_{18}$ column at room temperature. Peaks were monitored by UV absorbance at $302 \mathrm{~nm} .{ }^{\text {[78] }}$

Omeprazole and its derivatives were determined in liquid culture medium through HPLC method using a monolithic column for application in biotransformation studies with fungi. The separation was achieved using a monolithic Chromolith Fast gradient $\mathrm{RP} \mathrm{C}_{18}$ endcapped column, using a mobile phase consisting of $0.15 \%(\mathrm{v} / \mathrm{v})$ trifluoroacetic acid (TFA) in water (solvent A) and $0.15 \%$ $(\mathrm{v} / \mathrm{v})$ TFA in acetonitrile (solvent B), under gradient elution and detection at $220 \mathrm{~nm}$. ${ }^{\text {[79] }}$

RP-HPLC methods were developed for the determi- 
nation of ternary mixture of omeprazole, tinidazole and either clarithromycin or doxycycline. The analysis was performed on a $\mathrm{C}_{18}$ column through a gradient elution system using acetonitrile: methanol: water adjusted to $\mathrm{pH}$ 6.6. Drugs were detected at $277 \mathrm{~nm} .{ }^{[80]}$ Another method was developed for determination of the cited ternary complex which was based on using a $\mathrm{C}_{18}$ column with a mobile phase consisting of methanol and $0.06 \mathrm{M}$ sodium dihydrogen phosphate $(65: 35, \mathrm{v} / \mathrm{v})$ adjusted to $\mathrm{pH} 4.5$. The UV detector was operated at $260 \mathrm{~nm}^{\text {[81] }}$

\section{Miscellaneous methods:}

The electrochemical oxidation of omeprazole was studied either at a carbon paste electrode ${ }^{[82]}$ or on glassy carbon electrode $^{[83]}$ by cyclic differential-pulse voltammetry.

A differential pulse polarographic study at the static mercury drop electrode was developed for the determination of omeprazole and its degradation products. ${ }^{[84]}$

A capillary zone electrophoresis method was developed for the separation of omeprazole enantiomers. ${ }^{[85]}$

Omeprazole and its metabolites were determined in human plasma using automated solid phase extraction and micellar electrokinetic capillary electrophoresis. ${ }^{[86]}$

Flow injection chemiluminescence system was used for the determination of omeprazole. It was based on the chemiluminescence reaction of sodium hydrosulfite with $\mathrm{Ce}$ (IV) in the nitric acid solution. ${ }^{[87]}$

Fiqueiras et al., ${ }^{[88]}$ investigated the effect of L-arginine and cyclodextrins on omeprazole stability and solubility.

\section{Pantoprazole sodium}

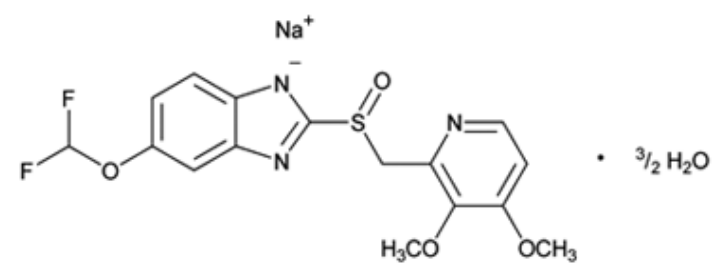

Chemical name:

5-(Difluoromethoxy)-2-[[(3,4-dimethoxy-2-pyridyl) methyl] sulfinyl] benzimidazole, sodium salt, sesquihydrate

Molecular formula: $\mathrm{C}_{16} \mathrm{H}_{14} \mathrm{~F}_{2} \mathrm{~N}_{3} \mathrm{NaO}_{4} \mathrm{~S} .1 .5 \mathrm{H}_{2} \mathrm{O}$

Molecular weight: 432.37

Physical properties:

Appearance: White to off-white crystalline powder

Solubility: Freely soluble in water

Melting point: About $140^{\circ} \mathrm{C}$

\section{Pharmacological action:}

Pantoprazole is a proton pump inhibitor, used as an antiulcerative agent by inhibiting the gastric acid secretion. It is immensely used for the cure of erosion and ulceration of esophagus caused by a gastroesophagal reflux disease. ${ }^{[3]}$

\section{Methods of determination:}

Pantoprazole is official in B.P. $2011^{[4]}$ and determined by non-aqueos titration and determining the end point potentiometrically, and in U.S.P. XXXII ${ }^{[2]}$ and determined by HPLC.

\section{Spectrophotometric methods:}

Moustafa A. A, ${ }^{[89]}$ described three procedures for the assay of pantoprazole in tablets. Two were based on charge transfere complex formation reaction using 2,3dichloro-5,6-dicyano-1,4-benzoquinone and iodine as $\pi$ acceptor and $\sigma$-acceptor, respectively. The third method was based on the formation of a ternary complex, involving $\mathrm{Cu}$ (II) and eosin as reagents.

The compensation method and other chemometric methods (derivative, orthogonal function and difference spectrophotometry) have been applied to the direct determination of pantoprazole in pharmaceutical preparations. $^{[61]}$

Spectrophotometric method was described for the determination of pantoprazole. This method was based on the formation of an ethanol-soluble colored chelate with iron (III). ${ }^{[62]}$

The first order UV-derivative spectrophotometry; applying zero-crossing method was developed for the determination of pantoprazole and its corresponding impurities. ${ }^{[63]}$

Pantoprazole was reacted with iron (III) and subsequent reacted with ferricyanide which yielded a prussion blue product with maximum absorption at $\lambda_{\max } 720 \mathrm{~nm} .^{[64]}$

Known excess of N-bromosuccinamide (NBS) added to pantoprazole in acid medium, followed by determination of unreacted oxidant by reacting with a fixed amount of either methyl orange and measuring absorbance at $\lambda_{\max }$ $520 \mathrm{~nm}$ or indigo carmine at $\lambda_{\max } 610 \mathrm{~nm} .^{\text {[90] }}$

Known excess of permanganate was added to pantoprazole in acid medium, followed by the measurement of the residual permanganate spectrophotometrically at $\lambda_{\max } 545 \mathrm{~nm}$. The amount of permanganate reacted corresponds to pantoprazole content. ${ }^{[91]}$

Furthermore, another spectrophotometric method was described for the determination of pantoprazole. This method was based on the reduction of ferric chloride by pantoprazole and subsequent chelation of iron (II) with 1,10-phenanthroline or 2,2'-bipyridyl. The resulting red colored products were measured at $\lambda_{\max } 510$ or $520 \mathrm{~nm}$, respectively. ${ }^{[92]}$

\section{Chromatographic methods:}

A multidimensional HPLC method was developed for 
the enantiometric determination pantoprazole in human plasma. This method was based on using a multidimensional HPLC by coupling a RAM column with a chiral polysaccharide column to the analysis of pantoprazole in human plasma by direct injection. The enantiomers from the plasma samples were separated with high resolution on a tris(3,5-dimethoxyphenylcarbamate) of amylose phase after clean-up by a RAM BSA octyl column. Water was used as solvent for the first 5 min for the elution of the plasmatic proteins and then acetonitrile-water (35: 65, $\mathrm{v} / \mathrm{v}$ ) for the transfer and analysis of pantoprazole enantiomers, which were detected by UV at $285 \mathrm{~nm}$. ${ }^{[3]}$

Another HPLC method was described for the determination of pantoprazole; using Hypersil $\mathrm{C}_{18}$ column, potassium dihydrogen phosphate $(\mathrm{pH} 4.7)$ : acetonitrile (720: $280, \mathrm{v} / \mathrm{v})$ as a mobile phase. ${ }^{[94]}$

RP-HPLC method was developed for the determination of pantoprazole in commercial products, using Intersil $\mathrm{C}_{18}$ column, acetonitrile: phosphate $(60: 40, \mathrm{v} / \mathrm{v})$ as a mobile phase and detection was carried out at $230 \mathrm{~nm} .{ }^{\text {[95] }}$

Another RP-HPLC method was described for simultaneous separation and quantification of pantoprazole and its impurities in pharmaceutical preparations. The separation was accomplished on a Zorbax Eclipse XDB $\mathrm{C}_{18}$ column using a gradient elution with mobile phase $\mathrm{A}$ [buffer: acetonitrile (70: 30, v/v)], and mobile phase B [buffer: acetonitrile (30: 70, v/v)]. The buffer was 0.01 $\mathrm{M}$ ammonium acetate solution with addition of $1 \mathrm{ml}$ triethylamine/L of the solution, adjusted to $\mathrm{pH} 4.5$ with orthophosphoric acid. The eluate was monitored at 290 nm. ${ }^{[96]}$

Stability-indicating TLC and HPLC methods were presented for simultaneous determination of mosapride and pantoprazole in pharmaceutical dosage form and plasma samples. The TLC method employed aluminum TLC plates precoated with silica gel as the stationary phase and ethyl acetate: methanol: toluene (4: 1: 2, v/v/v) as the mobile phase to give compact spots for mosapride (Rf 0.73) and pantoprazole ( Rf 0.45) separated from their degradation products; the chromatogram was scanned at $276 \mathrm{~nm}$. The HPLC method utilized a $\mathrm{C}_{18}$ column and a mobile phase consisting of acetonitrile: methanol: 20 $\mathrm{mM}$ ammonium acetate $(4: 2: 4, \mathrm{v} / \mathrm{v} / \mathrm{v})$ for the separation of mosapride and pantoprazole from their degradation products. Quantitation was achieved with UV detection at $280 \mathrm{~nm} \cdot{ }^{[97]}$

Furthermore, a reversed phase liquid chromatographic method was developed for the determination of cinitapride and pantoprazole sodium in their marketed formulation. A reversed phase $\mathrm{C}_{18}$ column with mobile phase consisting of acetonitrile: water: triethylamine (80: 20: $0.05, \mathrm{v} / \mathrm{v} / \mathrm{v})$ were used. The detection was set at 260 nm. [98]

Another stability-indicating HPLC method was reported for the determination of impurities in pantoprazole in bulk drug and in formulations. Resolution of drug, its potential impurities and degradation products were achieved on a Hypersil ODS column utilizing a gradient with $0.01 \mathrm{M}$ phosphate buffer of $\mathrm{pH} 7$ and acetonitrile as eluent, at the detection wavelength of $290 \mathrm{~nm} .{ }^{\text {[99] }}$

\section{Miscellaneous methods:}

Differential pulse anodic voltammetric method was described for the determination of pantoprazole in dosage forms and human plasma using glassy carbon electrode. The best voltammetric response was reached for a glassy carbon electrode in Britton-Robinson buffer solution of pH 5.0. ${ }^{[100]}$

A flow injection biamperometric method was developed for the determination of pantoprazole (PTZ) in pharmaceutical tablets. The reversible redox couples $\mathrm{Fe}^{3+} / \mathrm{Fe}^{2+}, \mathrm{Fe}(\mathrm{CN})_{6}{ }^{(3-)} / \mathrm{Fe}(\mathrm{CN}) 6^{(4-)}, \mathrm{Ce}^{4+} / \mathrm{Ce}^{3+}, \mathrm{NO}_{3}$ ${ }^{(-)} \mathrm{NO}_{3}{ }^{(+)}$, and $\mathrm{I}_{2} / \mathrm{I}^{-}$were tested as indicating redox systems for biamperometric determination of PTZ in a flow-injection assembly with optimized flow parameters. The best results were obtained using $\mathrm{NO}_{3}{ }^{(-)} \mathrm{NO}_{3}{ }^{(+)}$, which showed to be a selective and sensitive biamperometric indicating system for PTZ even in the presence of excipients and antioxidants that typically are found in pharmaceutical formulations. ${ }^{[101]}$

\section{Tinidazole}

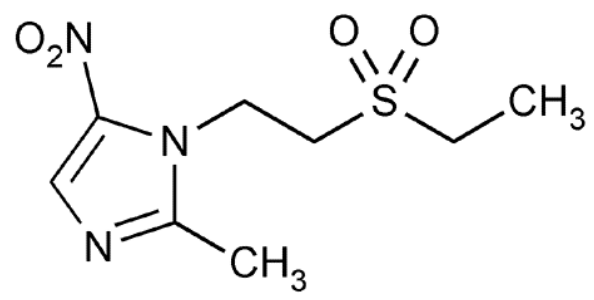

Chemical name:

1-(2-ethyl-sulphonyl ethyl)-2-methyl-5-nitroimidazole

Molecular formula: $\mathrm{C}_{8} \mathrm{H}_{13} \mathrm{~N}_{3} \mathrm{O}_{4} \mathrm{~S}$

Molecular weight: 247.28

Physical properties:

Appearance: White to pale yellow crystalline powder Solubility: Soluble in methanol and insoluble in water Melting point: About $128^{\circ} \mathrm{C}$

\section{Pharmacological action:}

Tinidazole is 5-nitroimidazole derivative with activity against anaerobic bacteria and protozoa. It is used to eradicate $\mathrm{H}$. pylori in peptic ulcer disease with other antimicrobials and proton pump inhibitor. ${ }^{[3]}$

\section{Methods of Determination:}


Tinidazole is official in B.P. 2011 $1^{[4]}$ and U.S.P. $\mathrm{XXXII}^{[2]}$ where it was determined in both pharmacopeias by non aqueous titration using perchloric acid and the end point was determined potentiometrically.

\section{Spectrophotometric methods:}

Reduced form of tinidazole as n-electron donor forms a charge-transfer complex with chloranilic acid as $\pi$ electron acceptor with an absorption band at $\lambda_{\max } 520$ nm. ${ }^{[102]}$

Ion-pair complex was formed between tinidazole and alizarin red $\mathrm{S}$ producing which can be measured at $\lambda_{\max }$ $420 \mathrm{~nm}^{[103]}$

Based on the reduction of the nitro group of tinidazole by $10 \% \mathrm{Pd}-\mathrm{C}$ and formic acid, the resulting amine was subjected to a condensation reaction with sodium 1,2naphthaquinone-4-sulfonate to give a red schiff's base measured at $\lambda_{\max } 510 \mathrm{~nm} \cdot{ }^{[104]}$

Two spectrophotometric methods were presented for estimation of tinidazole. The first one was based on that reduced drug interacted with 3-methylbenzothiazolin-2one hydrazone in presence of copper sulphate and acidic pyridine producing yellowish orange colour with $\lambda_{\max }$ $490 \mathrm{~nm}$. The second method was based on reaction of the reduced drug with $\mathrm{N}$-(1-naphthyl) ethylenediamine dihydrochloride yielding pink product with $\lambda_{\max } 505$ nm. ${ }^{[105]}$

Diazodized tinidazole reacted with $\mathrm{p}$ dimethylaminobenzaldehyde forming greenish yellow solution which measured spectrophotometrically at $\lambda_{\max }$ 404 nm. ${ }^{[106]}$

Direct UV-visible spectrophotometric and differential spectrophotometric methods were described for the determination of tinidazole in pure and dosage forms. ${ }^{[107]}$

Difference spectroscopic method was developed for the simultaneous determination of binary mixtures of norfloxacin and tinidazole without prior separation. ${ }^{[108]}$

Alhemiary $\mathrm{N}$ and Saleh $\mathrm{M},{ }^{[109]}$ described two spectrophotometic methods for the assay of reduced tinidazole. The first method was based on Schiff's base reaction using ethylvanillin and measuring the absorbance of yellow color at $\lambda_{\max } 470 \mathrm{~nm}$. Whereas the second method was based on oxidative coupling reaction using promethazine $\mathrm{HCl}$ and hypochlorite oxidation agent in alkaline medium, forming red color at $\lambda_{\max } 525 \mathrm{~nm}$.

A colored complex was formed between tinidazole and copper (II) acetate, extracted with chloroform and measured spectrophotometrically. ${ }^{[110]}$

\section{Chromatographic methods:}

Mahmoud M. Sebaiy et al., ${ }^{[11-114]}$ introduced four miscellaneous HPLC methods for determination of tinidazole in combination with different drug classes.

RP-HPLC method was developed for the simultaneous determination of tinidazole. The separation was carried out using a mobile phase consisting of acetonitrile: methanol: $0.2 \mathrm{M}$ potassium dihydrogen phosphate $(\mathrm{pH}$ 5 ) in the ratio of 2: 3: 2. The column used was SS Wakosil-II $\mathrm{C}_{18}$ and UV detection was set at $282 \mathrm{~nm}^{\left[{ }^{[15]}\right.}$ Another HPLC method was described based on using SS Wakosil-II $\mathrm{C}_{18}$ column with mobile phase composition of acetonitrile: phosphate buffer (pH 5) (3: 1, v/v) and UV detection at $295 \mathrm{~nm} .^{[116]}$

Stability-indicating method was described for the determination of ciprofloxacin and tinidazole using RP-UPLC method. The sample was analyzed by reverse phase Purospher Star $\mathrm{C}_{18}$ column as stationary phase and phosphate buffer: acetonitrile (80: 20, v/v) as a mobile phase and pH 3.0 was adjusted by ortho-phosporic acid. Quantification was achieved of ciprofloxacin $\mathrm{HCl}$ at $278 \mathrm{~nm}$ and of tinidazole at $317 \mathrm{~nm} .{ }^{[117]}$

Isocratic RP-HPLC method was developed for the determination of amoxicillin, tinidazole and omeprazole in combined dosage forms. The three compounds were monitored at $230 \mathrm{~nm}$ using an isocratic mode on Inertsil ODS $\mathrm{C}_{18}$ column and a mobile phase consisting of methanol: acetonitrile: water in a ratio of (49: 49: $2, \mathrm{v} / \mathrm{v} / \mathrm{v}) .{ }^{[118]}$

\section{Miscellaneous methods:}

Resonance light scattering technique was used to determine tinidazole by using tetraphenylboron sodium (TPB). Tinidazole was found to bind $\mathrm{B}\left(\mathrm{C}_{6} \mathrm{H}_{5}\right)_{4}^{-}$anion and transformed to tinidazole-TPB aggregate which displayed intense resonance scattering light. ${ }^{[19]}$

Capillary electrophoresis with UV photo-diode array detection technique was described for the analysis of tinidazole and norfloxacin in pharmaceuticals. This method utilized $32.5 \mathrm{mmol} / \mathrm{L}$ phosphate electrolyte at $\mathrm{pH} 2.5$, voltage $25 \mathrm{kv}$ and column temperature $25^{\circ} \mathrm{C}$ with detection at wavelength $301 \mathrm{~nm}^{\left[{ }^{120]}\right.}$

A multisyringe flow injection analysis method for the determination of tinidazole in pharmaceutical preparations was developed. Tinidazole concentrations were determined by spectrophotometric detection at $\lambda_{\max } 374$ nm using a light emitting diode. ${ }^{[121]}$

\section{Doxycycline hyclate}

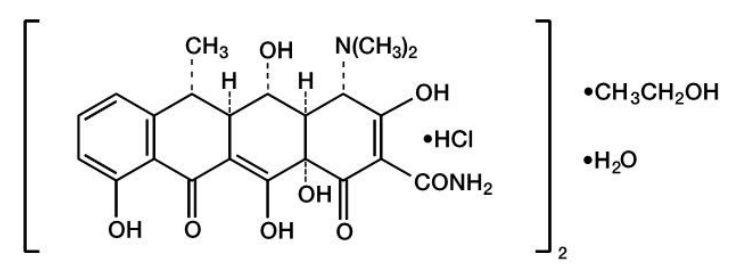


Chemical name:

4-(Dimethylamino)-1,4,4a,5,5a,6,11,12a-octahydro3,5,10,12,12a-pentahydroxy-6-methyl-1,11-dioxo-2naphthacenecarboxamide monohydrochloride

Molecular formula: $\left(\mathrm{C}_{22} \mathrm{H}_{24} \mathrm{~N}_{2} \mathrm{O}_{8} \cdot \mathrm{HCl}\right)_{2} \mathrm{C}_{2} \mathrm{H}_{6} \mathrm{O}$, $\mathrm{H}_{2} \mathrm{O}$

Molecular weight: 1025.89

Physical properties:

Appearance: Yellow crystalline powder

Solubility: Soluble in water and in methanol

\section{Pharmacological action:}

Doxycycline is a tetracycline derivative which is bacteriostatic with a broad spectrum of antimicrobial activity including many aerobic and anaerobic Gram-positive and Gram-negative pathogenic bacteria and some protozoa. It is used in triple therapy along with tinidazole and proton pump inhibitor in the treatment of peptic ulcer. ${ }^{[3]}$

\section{Methods of determination:}

Doxycycline hyclate is official in B.P. $2011^{[4]}$ and U.S.P. $\mathrm{XXXII}^{[2]}$ and it was determined in both pharmacopeias by liquid chromatography method.

\section{Spectrophotometric methods:}

A spectrophotometric method was described for the determination of doxycycline. The method was based on the formation of blue colored chromogen measured at $\lambda_{\max } 770 \mathrm{~nm}$ due to reduction of tungstate and/or molybdate in Folin-Ciocalteu reagent by doxycycline in alkaline medium. ${ }^{[122]}$

Rufino et al. ${ }^{[123]}$ described a simple spectrophotometric method for the determination of doxycycline. The method was based on the reaction between the drug and chloramine $\mathrm{T}$ in alkaline medium; producing red color with maximum absorbance at $\lambda_{\max } 525 \mathrm{~nm}$.

Yellow ion pair complexes were formed between doxcycline and bromocresol green and methyl orange in BrittonRobinson buffer of $\mathrm{pH} 3$ and 2.2, respectively; measuring the complexes at $\lambda_{\max } 424 \mathrm{~nm}$ and $480 \mathrm{~nm}$. Moreover, Formation of charge transfer complexes were reported between doxycycline and tetracyanoethylene and 7,7,8,8tetracyanoquinodimethane. ${ }^{[124]}$

\section{Spectrofluorimetric methods:}

Li-Wei et al., ${ }^{[125]}$ described a spectrofluorimetric method for the determination of trace doxycycline with diethyl-O- $\beta$-cyclodextrin doxycycline- $\mathrm{Eu}^{3+}$ system.

Another spectrofluorimetric assessment of doxycycline hydrochloride in tablets and serum sample was developed. The method was based on the enhancement of luminescence intensity of the optical sensor $\mathrm{Sm}^{3+}$ ion. ${ }^{[126]}$

\section{Chromatographic methods:}

Several HPLC methods were developed for the determination of doxycycline in human plasma, serum and biological tissues. ${ }^{[127-129]}$

HPLC method was developed for the separation of doxycycline and its degradation products. The separation was achieved by using Phenomenex Luna $\mathrm{C}_{8}$ column, and a mobile phase consisting of acetonitrile: water: perchloric acid (26: 74: 0.25, v/v/v) adjusted to $\mathrm{pH} 2.5$ with $5 \mathrm{M}$ sodium hydroxide and ultraviolet detection at 350 nm. ${ }^{[130]}$

Another HPLC method was developed for estimation of doxycycline in bulk, tablets and capsules after storage in different temperature for testing thermostability of doxycycline. The samples were eluted from a Bondapak $\mathrm{C}_{8}$ column with a mobile phase of acetonitrile: water: tetrahydrofuran (29.5: 70: 0.5, v/v/v), adjusted to $\mathrm{pH} 2.5$ with $1.0 \mathrm{M} \mathrm{HCl}$. The detection by UV was at $350 \mathrm{~nm}$. The stability of doxycycline in bulk and in pharmaceuticals was checked over 90 days. Doxycycline showed thermo-degradation after exposure to high temperature; tablets were more stable than capsules. ${ }^{[131]}$

Mitic et al., ${ }^{[132]}$ developed HPLC method for quantification of doxycyline in pharmaceutical samples; using Lichrosorb RP-C 8 column and mixture of methanol: acentonitrile: $0.01 \mathrm{M}$ aqueous solution of oxalic acid (2: 3: 5 , $\mathrm{v} / \mathrm{v} / \mathrm{v}$ ) as a mobile phase.

Liquid chromatography-mass spectrometric method was described and validated for the quantification of doxycycline in human plasma. The liquid chromatographic separations were carried out by using Cadenza $\mathrm{C}_{18}$ column. The mobile phase was composed of $0.04 \%$ trifluoroacetic acid in (methanol: acetonitrile: water (47.5: 47.5: $5, \mathrm{v} / \mathrm{v} / \mathrm{v})$. Mass spectrometer was used for detection. ${ }^{[133]}$

\section{Miscellaneous methods:}

The polarographic behavior of doxycycline was studied in phosphate buffer at different pH (2-9). ${ }^{[134]}$ Flowinjection spectrophotometric and liquid chromatographic methods were used for the determination of doxycyline in biological fluids and pharmaceutical preparations. In spectrophotometric method, zirconyl chloride formed a yellow complex with doxycycline in acidic medium measured at $\lambda_{\max } 390 \mathrm{~nm}$. Where in HPLC method, reversed phase $\mathrm{C} 18$ column was used. The mobile phase composed of $29.5 \%$ acetonitrile, $70 \%$ of $0.1 \mathrm{M}$ oxalate buffer $(\mathrm{pH}$ $2.5)$ and $0.5 \%$ triethylamine. ${ }^{[135]}$

Flow-injection spectrophotometric method was developed for the determination of doxycycline in pharmaceutical formulations with chloramine $\mathrm{T}$ as oxidizing agent. $^{[136]}$

The utility of carbon paste electrode was demonstrated 
for the determination of doxycycline hydrochloride modified with doxycycline-tetraphenyl borate ion-pair. ${ }^{[137]}$

Electrochemical behavior of doxycycline was investigated by the differential pulse voltammetric method.

\section{Conclusion}

This literature review represents an up to date survey about all reported methods that have been developed for determination of Ranitidine hydrochloride, Famotidine, Omeprazole, Pantoprazole sodium, Tinidazole and Doxycycline hyclate in their pure form, combined form with other drugs, combined form with degradation products, and in biological samples such as liquid chromatography, spectrophotometry, spectroflourimetry, electrophoresis, etc.

\section{References}

[1] Graham L. Patrick. An introduction to Medicinal Chemistry, 5th edition, 2013.

[2] The United States Pharmacopoeia, XXXII, The National Formulary, United States Pharmacopeial Convention, Inc, 2010.

[3] Sweetman SC. Martindale-The Complete Drug Reference, 37th edition, The Pharmaceutical Press, London. 2011.

[4] The British Pharmacopoeia, HM Stationery Office, London, 2011.

[5] Perez-Ruiz T, Martinez-Lozano C, Tomas V, et al. Flowinjection extraction-spectrophotometric method for the determination of ranitidine in pharmaceutical preparations. Journal of Pharmaceutical and biomedical analysis, 2001, 26(4): 609-615.

https://doi.org/10.1016/S0731-7085(01)00489-7

[6] Kelani KM, Aziz AM, Hegazy MA, et al. Uvspectrophotometric stability indicating methods for the quantitative determination of cimetidine, famotidine, and ranitidine hydrochloride in the presence of their oxidative derivatives. Analytical Letters, 2002, 35(6): 1055-1073.

https://doi.org/10.1081/AL-120004555

[7] Basavaiah K and Nagegowda P. Determination of ranitidine hydrochloride in pharmaceutical preparations by titrimetry and visible spectrophotometry using bromate and acid dyes. IL Farmaco, 2004, 59: 147-153. https://doi.org/10.1016/j.farmac.2003.11.012

[8] Basavaiah K and Nagegowda P. Determination of ranitidine using potassium iodate and dichlorofluorescein. Indian Journal of Chemical Technology, 2004, 11(1): 11-16.

[9] Basavaiah K, Nagegowda P and Ramakrishna V. Determination of drug content of pharmaceuticals containing ranitidine by titrimetry and spectrophotometry in nonaqueous medium. Science Asia, 2005, 31: 207-214. https://doi.org/10.2306/scienceasia1513-1874.2005.31.207

[10] Walash IM, Sharaf El-Din KM, Metwally EM, et al. Kinetic Spectrophotometric Determination of Ranitidine. Journal of the Chinese Chemical Society, 2013, 51(3): 523-530. https://doi.org/10.1002/jccs.200400079
[11] Basavaiah K and Somashekar BC. Quantitation of ranitidine in pharmaceuticals by titrimetry and spectrophotometry using potassium dichromate as the oxidimetric reagent. Journal of the Iranian Chemical Society, 2007, 4(1): 78-88. https://doi.org/10.1007/BF03245806

[12] Darwish AI, Hussein AS, Mahmoud A, et al. A sensitive spectrophotometric method for the determination of $\mathrm{H} 2$ receptor antagonists by means of $\mathrm{N}$-bromosuccinimide and p-aminophenol. Acta Pharm, 2008, 58: 87-97. https://doi.org/10.2478/v10007-007-0047-z

[13] Narayana B, Ashwini K, Divya NS, et al. Spectrophotometric determination of ranitidine hydrochloride based on the reaction with p-dimethylaminobenzaldehyde. Eurasian Journal of Analytical Chemistry, 2010, 5(1): 63-72.

[14] Narayana B, Veena K and Divya NS. New reagents for the spectrophotometric determination of ranitidine hydrochloride. Ecletica Quimica, 2010, 35(3): 109-115. https://doi.org/10.1590/S0100-46702010000300010

[15] Khalil MM, Frag EY, Mohamed GG, et al. Spectrophotometric studies using ion-pair formations of Ranitidine hydrochloride in pure and in Pharmaceutical forms with some dyestuff reagents. Journal of Applied Pharmaceutical Science, 2013, 3(4): 92-98.

[16] Abdel Kader SA, Abdel Kawy $M$ and Nebsen $M$. Spectrophotometric and Spectrofluorimetric Determination of Famotidine and Ranitidine Using 1,4-Benzoquinone Reagent. Analytical Letters, 1999, 32(7): 1403-1419. https://doi.org/10.1080/00032719908542906

[17] Ulu ST and Cakar MB. A sensitive spectrofluorimetric method for the determination of ranitidine hydrochloride in pharmaceutical preparation. Optics and spectroscopy, 2012, 113(2): 126-130. https://doi.org/10.1134/S0030400X12080164

[18] Ho C, Huang HM, Hsu SY, et al. Simultaneous highperformance liquid chromatographic analysis for famotidine, ranitidine $\mathrm{HCl}$, cimetidine, and nizatidine in commercial products. Drug development and industrial pharmacy, 1999, 25(3): 379-385. https://doi.org/10.1081/DDC-100102186

[19] Novakovic J. High-performance thin-layer chromatography for the determination of ranitidine hydrochloride and famotidine in pharmaceuticals. Journal of Chromatography A, 1999, 846(1-2): 193-198. https://doi.org/10.1016/S0021-9673(99)00510-5

[20] Kelani MK, Aziz AM, Hegazy MA, et al. Determination of Cimetidine, Famotidine, and Ranitidine Hydrochloride in the Presence of Their Sulfoxide Derivatives in Pure and Dosage Forms by High-Performance Thin-Layer Chromatography and Scanning Densitometry. Journal of AOAC international, 2002, 85(5): 1015-1020. https://doi.org/10.1093/jaoac/85.5.1015

[21] Zendelovska D and Stafilov T. Development of an HPLC method for the determination of ranitidine and cimetidine in human plasma following SPE. Journal of Pharmaceuticals and biomedical analysis, 2003, 33(2): 165-173. https://doi.org/10.1016/S0731-7085(03)00265-6

[22] Nascimento TG, Oliveira Ede J and Macedo RO. Simultaneous determination of ranitidine and metronidazole in human plasma using high performance liquid chromatography with diode array detection. Journal of Pharmaceuticals and 
biomedical analysis, 2004, 37(4): 777-783.

https://doi.org/10.1016/j.jpba.2004.11.042

[23] Kokoletsi MX, Kafkala S and Tsiaganis M. A novel gradient HPLC method for simultaneous determination of ranitidine, methylparaben and propylparaben in oral liquid pharmaceutical formulation. Journal of Pharmaceuticals and Biomedical analysis, 2005, 38(4): 763-767. https://doi.org/10.1016/j.jpba.2005.02.022

[24] Arayne SM, Sultana N, Zuberi HM, et al. Simultaneous Determination of Metformin, Cimetidine, Famotidine, and Ranitidine in Human Serum and Dosage Formulations Using HPLC with UV Detection. Journal of Chromatographic Science, 2010, 48(9): 721-725. https://doi.org/10.1093/chromsci/48.9.721

[25] Sharma N, Rao SS, Kumar DA, et al. A Validated StabilityIndicating Liquid-Chromatographic Method for Ranitidine Hydrochloride in Liquid Oral Dosage Form. Scientia Pharmaceutica, 2011, 79: 309-322.

https://doi.org/10.3797/scipharm.1101-06

[26] Ulu ST and Tuncel M. A Sensitive and Rapid Determination of Ranitidine in Human Plasma by HPLC with Fluorescence Detection and its Application for a Pharmacokinetic Study. Journal of Chromatographic Science, 2012, 50(4): 301-306. https://doi.org/10.1093/chromsci/bms003

[27] Majidano AS and Khuhawar YM. GC Determination of Famotidine, Ranitidine, Cimetidine, and Metformin in Pharmaceutical Preparations and Serum Using Methylglyoxal as Derivatizing Reagent. Chromatographia, 2012, 75(21-22): 1311-1317. https://doi.org/10.1007/s10337-012-2321-6

[28] El-Bayoumi AE, El-Shanawany A, El-Sadek EM, et al. Stability indicating spectrodensitometric determination of ranitidine hydrochloride using linear and non-linear regression. Journal of Pharmaceutical and Biomedical Analysis, 1999, 21(4): 867-873. https://doi.org/10.1016/S0731-7085(99)00146-6

[29] Wu SM, Ho YH, Wu HL, et al. Simultaneous determination of cimetidine, famotidine, nizatidine, and ranitidine in tablets by capillary zone electrophoresis. Electrophoresis, 2001, 22(13): 2758-2761. https://doi.org/10.1002/1522-2683(200108)22:13〈2758:: AID-ELPS2758 $>3.0 . C O ; 2-\mathrm{P}$

[30] Issa YM, Badawy SS and Mutair AA. Ion-Selective Electrodes for Potentiometric Determination of Ranitidine Hydrochloride, Applying Batch and Flow Injection Analysis Techniques. Analytical Sciences, 2005, 21(12): 1443-1448. https://doi.org/10.2116/analsci.21.1443

[31] Tang YH, Wang NN, Xiong XY, et al. A new sensitive flowinjection chemiluminescence method for the determination of H(2)-receptor antagonists. Luminescence, 2007, 22(4): 343-348

https://doi.org/10.1002/bio.969

[32] Frag EY, Mohamed AM, Mohamed GG, et al. Construction and Performance Characterization of Ion Selective Electrodes for Potentiometric Determination of Ranitidine Hydrochloride in Pharmaceutical Preparations and Biological Fluids. International Journal of Electrochemical Science, 2011, 6: 3508-3524.
[33] Chang YX, Qiu YQ, Du LM, et al. Determination of ranitidine, nizatidine, and cimetidine by a sensitive fluorescent probe. Analyst, 2011, 136(20): 4168-4173. https://doi.org/10.1039/c1an15078b

[34] Mohamed GG, Khalilb MM, Frag EY, et al. Potentiometric determination of ranitidine hydrochloride utilizing modified carbon paste electrodes. International Journal of current Pharmaceutical Research, 2013, 5(2): 72-79.

[35] Chukwwurah BK and Ajali U. Quantitative determination of famotidine through charge-transfer complexation with chloranilic acid. Bollettino Chimico Farmaceutica, 2001, 140(5): 354-360.

[36] Al-Ghannam S. Spectrophotometric Determination of Three Anti-Ulcer Drugs Through Charge-Transfer Complexation. Journal of AOAC International, 2002, 85(5): 1003-1008.

https://doi.org/10.1093/jaoac/85.5.1003

[37] Amin AS, Shama SA, Ahmed IS, et al. Spectrophotometric determination of famotidine through oxidation with nbromosuccinimide and cerric sulphate. Analytical Letters, 2002, 35(1): 1851-1862.

https://doi.org/10.1081/AL-120013588

[38] Alazazy MS, Shalaby A, Elbolkiny MN, et al. Spectrophotometric determination of aciclovir, ceftazidime pentahydrate, famotidine and isoxsuprine hydrochloride by ternary complex formation with eosin and $\mathrm{Cu}$ (II). Chinese Pharmaceutical Journal, 2003, 55(6): 481-490.

[39] Nafisur R and Kashif M. Application of ninhydrin to spectrophotometric determination of famotidine in drug formuiations. IL Farmaco, 2003, 58(10): 1045-1050. https://doi.org/10.1016/S0014-827X(03)00184-8

[40] Ayad MM, Shalaby A, Abdellatef HE, et al. New colorimetric methods for the determination of trazodone $\mathrm{HCl}$, famotidine, and diltiazem $\mathrm{HCl}$ in their pharmaceutical dosage forms. Analytical and Bioanalytical Chemistry, 2003, 376(5): 710-714. https://doi.org/10.1007/s00216-003-1954-6

[41] Koricanac Z, Jovanovic T, Petkovic J, et al. Spectrophotometric investigation of famotidine-Pd(II) complex and its analytical application in drug analysis. Journal of the Serbian Chemical Society, 2004, 69(6): 485-491. https://doi.org/10.2298/JSC0406485K

[42] Walash MI, Sharaf-El-Din MK, Metwally ME, et al. Kinetic Spectrophotometric Determination of Famotidine in Pharmaceutical Preparations. Journal of Chinese Society, 2005, 52: 71-76. https://doi.org/10.1002/jccs.200500011

[43] Reddy NR, Prabhavathi K, Bhaskar RY, et al. A new spectrophotometric determination of famotidine from tablets. Indian Journal of Pharmaceutical Science, 2006, 68: 645-647. https://doi.org/10.4103/0250-474X.29637

[44] Darwish IA, Hussein SA, Mohmoud AM, et al. Sensitive Indirect Spectrophotometric Method for Determination of H2Receptor Antagonists in Pharmaceutical Formulations. International Journal of Biomedical Science, 2007, 3(2): 124131.

[45] Basavaih K and Zenita O. Spectrophotometric determination of famotidine using sulphonphthalein dyes. Quimica Nova, 2011, 34(5). https://doi.org/10.1590/S0100-40422011000500002 
[46] Dipali DT, Sacchidanand RG, Aditi RS, et al. Spectrophotometric Simultaneous Determination of Famotidine and Domperidone in Combined Tablet Dosage Form by Ratio Derivative and Area under Curve Method. Der Pharmacia Sinica, 2011, 2(3): 60-66.

[47] Araujo L, Perdomo N, Montiel R, et al. Spectrophotometric methods for the determination of famotidine in drug formulations. International Journal of Advances in Pharmaceutical analysis, 2012, 2(1): 24-29. https://doi.org/10.7439/ijapa.v2i1.15

[48] Walash MI, El-Brashy A, El-Enany N, et al. Spectrofluorimetric Determination of Famotidine in Pharmaceutical Preparations and Biological Fluids through Ternary Complex Formation with Some Lanthanide Ions: Application to Stability Studies. International Journal of Biomedical Science, 2009, 5(2): 158-168.

[49] Walash MI, El-Brashy A, El-Enany N, et al. Spectrofluorimetric determination of famotidine in pharmaceutical preparations and biological fluids through reaction with 1,10 phenanthraquinone. Application to stability studies. Journal of fluorescence, 2009, 19(2): 333-344. https://doi.org/10.1007/s10895-008-0421-3

[50] Dowling TC and Frye RF. Determination of famotidine in human plasma and urine by high-performance liquid chromatography. Journal of chromatography B: Biomedical sciences and Applications, 1999, 732(1): 239-243. https://doi.org/10.1016/S0378-4347(99)00269-8

[51] Zhong L, Eisenhandler R and Yeh KC. Determination of famotidine in low-volume human plasma by normal-phase liquid chromatography/tandem mass spectrometry. Journal of mass spectrometry, 2001, 36(7): 736-741. https://doi.org/10.1002/jms.176

[52] Eva A, Filipova K, Nobilis M, et al. Selective determination of famotidine in human plasma by high performance liquid chromatography in alkaline media with solid phase extraction. Journal of Separation Science, 2003, 26(8): 722-726. https://doi.org/10.1002/jssc.200301377

[53] Helali N, Darghouth F and Monser L. RP-HPLC Determination of Famotidine and its Potential Impurities in Pharmaceuticals. Chromatographia, 2004, 60(7-8): 455-460. https://doi.org/10.1365/s10337-004-0386-6

[54] Zarghi A, Shafaati A, Froutan SM, et al. Development of a rapid HPLC method for determination of famotidine in human plasma using a monolithic column. Journal of Pharamceutical and Biomedical analysis, 2005, 39(3-4): 677-680. https://doi.org/10.1016/j.jpba.2005.03.029

[55] Campbell AN and Sherma J. Determination of famotidine in acid reduction tablets by HPTLC and videodensitometry of fluorescence quenched zones. Journal of Liquid Chromatography and Related Technologies, 2003, 26(16): 2719-2727. https://doi.org/10.1081/JLC-120024542

[56] Reddy YR, Kumar KK, Reddy M, et al. RP-UPLC method development and validation for the simultaneous estimation of ibuprofen and famotidine in pharmaceutical dosage form. Pharmaceutical methods, 2012, 3(2): 57-61. https://doi.org/10.4103/2229-4708.103873

[57] Ayad MM, Shalaby A, Abdellatef HE, et al. Potentiometric determination of famotidine in pharmaceutical formulations. Journal of pharmaceutical and biomedical analysis, 2002, 29(1-2): 247-254. https://doi.org/10.1016/S0731-7085(02)00024-9
[58] Helali N, Adhoum N and Monser L. Flow injection kinetic spectrophotometric method for the determination of famotidine in pharmaceutical preparations. Journal of Flow Injection Analysis, 2005, 22(2): 129-133.

[59] Tiwari DC, Rajeev J and Gaurav S. Electrochemical behaviour of famotidine in pharmaceutical formulation at composite polymer membrane electrode. Indian Journal of Chemical Technology, 2008, 15: 472-475.

[60] El-Kousy NM and Bebawy LI. Stability-indicating methods for determining omeprazole and octylonium bromide in the presence of their degradation products. Journal of AOAC International, 1999, 82(3): 599-606. https://doi.org/10.1093/jaoac/82.3.599

[61] Wahbi AA, Abdel-Razak O, Gazy AA, et al. Spectrophotometric determination of omeprazole, lansoprazole and pantoprazole in pharmaceutical formulations. Journal of Pharmaceutical and biomedical analysis, 2002, 30(4): 11331142. https://doi.org/10.1016/S0731-7085(02)00464-8

[62] Salama F, El-Abasawy N, Abdel-Razeq SA, et al. Validation of the spectrophotometric determination of omeprazole and pantoprazole sodium via their metal chelates. Journal of Pharmaceutical and biomedical analysis, 2003, 33(3): 411421 https://doi.org/10.1016/S0731-7085(03)00233-4

[63] Karljikovic-Rajic K, Novovic D, Marinkovic V, et al. Firstorder UV-derivative spectrophotometry in the analysis of omeprazole and pantoprazole sodium salt and corresponding impurities. Journal of Pharmaceutical and Biomedical Analysis, 2003, 32(4-5): 1019-1027. https://doi.org/10.1016/S0731-7085(03)00204-8

[64] Syed AA and Syeda A. Spectrophotometric determination of certain benzimidazole proton pump inhibitors. Indian Pharmaceutical Sciences, 2008, 70: 507-510. https://doi.org/10.4103/0250-474X.44605

[65] Ahmed SS, Santosh RK, Simpi CC, et al. Visible spectrophotometric methods for the estimation of losartan potassium and omeprazole in single component pharmaceutical formulations. International Journal of Pharm Tech Research, 2009, 1(4): 1247-1250.

[66] Bhandage A, Bhosale A, Kasture A, et al. Extractive Spectrophotometric Determination of Omeprazole in Pharmaceutical Preparations. Tropical Journal of Pharmaceutical Research, 2009, 8(5): 449-454. https://doi.org/10.4314/tjpr.v8i5.48089

[67] Mahmoud AM. New Sensitive Kinetic Spectrophotometric Methods forDetermination of Omeprazole in Dosage Forms. International Journal of Analytical Chemistry, 2009, Article ID 307045 . https://doi.org/10.1155/2009/307045

[68] Bhuva SD and Patel MM. Spectrophotometric simultaneous estimation of Omeprazole and Cinitapride in bulk and formulation. Asian Journal of Pharmaceutical and Clinical Research, 2012, 5(4): 40-42.

[69] Lotfy HM and Abdel-Monem HM. Comparative study of novel spectrophotometric methods manipulating ratio spectra: an application on pharmaceutical ternary mixture of omeprazole, tinidazole and clarithromycin. Spectrochimica Acta. Part A, Molecular and Bimolecular spectroscopy, 2012, 96: 259-270 https://doi.org/10.1016/j.saa.2012.04.095 
[70] Ashour S and Bayram R. Validated Spectrophotometric Method for Determination of Some Benzimidazole Derivatives in Pharmaceutical Formulations Using 1,2naphthoquinone-4-sulphonate. International research journal of Pure and Applied chemistry, 2013, 3(2): 118-132. https://doi.org/10.9734/IRJPAC/2013/3160

[71] Shaghaghi M, Manzoori JL and Jouyban A. Indirect spectrofluorimetric determination of omeprazole by its quenching effect on the fluorescence of Tb3+-1,10-phenanthroline complex in presence of bis (2-ethylhexyl) sulfosuccinate sodium in caps. DARU Journal of Pharmaceutical Sciences, 2008, 16(4): 256-262.

[72] Sluggett GW, Stong JD, Adams JH, et al. Omeprazole determination using HPLC with coulometric detection. Journal of Pharmaceutical and Biomedical Analysis, 2001, 25(3-4): 357-361 https://doi.org/10.1016/S0731-7085(00)00519-7

[73] El-sherif ZA, Mohamed OA, El-Bardicy MG, et al. Reversed-Phase High Performance Liquid Chromatographic Method for the Determination of Lansoprazole, Omeprazole and Pantoprazole Sodium Sesquihydrate in Presence of Their Acid-Induced Degradation Products. Chemical Pharmaceutical Bulletin, 2006, 54(6): 814-818. https://doi.org/10.1248/cpb.54.814

[74] Murakami FS, Cruz AP, Pereira RN, et al. Development and validation of a RP-HPLC method to quantify omeprazole in delayed release tablets. Journal of Liquid Chromatography and related Technologies, 2007, 30(1): 113-121. https://doi.org/10.1080/10826070601034485

[75] Raval PB, Puraik M, Wadher SJ, et al. A validated HPTLC method for determination of ondansetron in combination with omeprazole or rabeprazole in solid dosage form. Indian Journal of Pharmaceutical Sciences, 2008, 70(3): 386-390. https://doi.org/10.4103/0250-474X.43011

[76] Dedania Z, Dedania R, Karkhanis V, et al. RP-HPLC method for simultaneous estimation of omeprazole and ondansetron in combined dosage forms. Asian Journal of Research Chemistry, 2009, 2(2): 108-111.

[77] Rezk NL, Briwn KC and Kashuba AM. A simple and sensitive bioanalytical assay for simultaneous determination of omeprazole and its three major metabolites in human blood plasma using RP-HPLC after a simple liquid-liquid extraction procedure. Journal of Chromatography B, 2006, 844: 314-321. https://doi.org/10.1016/j.jchromb.2006.07.047

[78] Nahar K, Joti J, Ullah MA, et al. A simple RPHPLC method for the determination of omeprazole in human serum and urine: Validation and application in pharmacokinetic study. Journal of Pharmaceutical Sciences, 2009, 8(2): 123-130. https://doi.org/10.3329/dujps.v8i2.6026

[79] Borges KB, Duran-Patron R, Sanchez AJ, et al. Fast HPLC Analysis of Omeprazole, 5-Hydroxyomeprazole and Omeprazole Sulfone in Liquid Culture Medium using a Monolithic Column for Application in Biotransformation Studies with Fungi. Journal of Brazalian Chemical Society, 2011, 22(6): 1140-1149. https://doi.org/10.1590/S0103-50532011000600020

[80] Darwish KM, Salama I, Mostafa S, et al. RP-HPLC/precolumn derivatization for analysis of omeprazole, tinidazole, doxycycline and clarithromycin. Journal of Chromatographic Science, 2012, 51(6): 566-576. https://doi.org/10.1093/chromsci/bms167
[81] Walash MI, Ibrahim F and Abo El-Abass S. Isocratic RPHPLC method for separation and simultaneous determination of ternary mixture of omeprazole, tinidazole and doxycycline in their raw materials and combined capsules. Analytical methods, 2013, 5(19): 5105-5111. https://doi.org/10.1039/c3ay41029c

[82] Radi A. Anodic voltammetric assay of lansoprazole and omeprazole on a carbon paste electrode. Journal of pharmceutical and Biomedical Analysis, 2003, 31(7): 1007-1012. https://doi.org/10.1016/S0731-7085(02)00707-0

[83] Yan JL. Electrochemical behavior and the determination of omeprazole using glassy carbon electrode. Journal of Applied Sciences, 2006, 6(7): 1625-1627. https://doi.org/10.3923/jas.2006.1625.1627

[84] Qaisi AM, Tutunji MF and Tutunji LF. Acid decomposition of omeprazole in the absence of thiol: a differential pulse polarographic study at the static mercury drop electrode (SMDE). Journal of Pharmaceutical Sciences, 2006, 95(2): 384-391. https://doi.org/10.1002/jps.20546

[85] Nevado JB, Penalvo GC and Dorado RR. Method development and validation for the separation and determination of omeprazole enantiomers in pharmaceutical preparations by capillary electrophoresis. Analytica Chimica Acta, 2005, 533(2): 127-133. https://doi.org/10.1016/j.aca.2004.11.018

[86] Perez-Ruiz T, Martinez-Lozano C, Sanz A, et al. Determination of omeprazole, hydroxyomeprazole and omeprazole sulfone using automated solid phase extraction and micellar electrokinetic capillary chromatography. Journal of pharmaceutical and Biomedical Analysis, 2006, 42(1): 100-106. https://doi.org/10.1016/j.jpba.2005.09.029

[87] Shu-hua H. Determination of Omeprazole by Flow Injection Combined with Chemiluminescence. Journal of Analytical Sciences, 2007, 23(1): 51-53.

[88] Fiqueiras A, Sarraquca JM, Pais AA, et al. The role of L-arginine in inclusion complexes of omeprazole with cyclodextrins. AAPS Pharm SciTech, 2010, 11(1): 233-240. https://doi.org/10.1208/s12249-009-9375-2

[89] Moustafa AA. Spectrophotometric methods for the determination of lansoprazole and pantoprazole sodium sesquihydrate. Journal of Pharmaceutical and Biomedical Analysis, 2000, 22: 45-48. https://doi.org/10.1016/S0731-7085(99)00275-7

[90] Basavaiah K, Anilkumar UR and Tharpa K. Spectrophotometric Determination of Pantoprazole Sodium in Pharmaceuticals Using N-Bromosuccinimide, Methyl Orange and Indigo Carmine as Reagents. Iranian Journal of Chemistry and Chemical engineering, 2009, 28(1): 31-36.

[91] Basavaiah K, Rajendraprasad N, Tharpa K, et al. Titrimetric and spectrophotometric assay of pantoprazole in pharmaceuticals using permanganate. Journal of Mexican Chemical Society, 2009, 53(1): 34-40. https://doi.org/10.29356/jmcs.v53i1.1015

[92] Devi OZ and Basavaiah K. Validated spectrophotometric determination of pantoprazole sodium in pharmaceuticals using ferric chloride and two chelating agents. International Journal of Chem Tech Research, 2010, 2(1): 624-632. https://doi.org/10.2298/CICEQ090617005B 
[93] Cass QB, Degani AL, Cassiano NM, et al. Enantiomeric determination of pantoprazole in human plasma by multidimensional high-performance liquid chromatography. Journal of Chromatography B: Analytical Technologies in the Biomedical and Life Sciences, 2002, 766(1): 153-160. https://doi.org/10.1016/S0378-4347(01)00472-8

[94] Patel BH, Suhagia BN, Patel MM, et al. Determination of pantoprazole, rabeprazole, esomeprazole, domperidone and itopride in pharmaceutical products by reversed phase liquid chromatography using single mobile phase. Chromatographia, 2007, 65: 743-748.

https://doi.org/10.1365/s10337-007-0220-z

[95] Reddy PB, Jayaprakash M, Sivaji K, et al. Determination of pantoprazole sodium and lansoprazole in individual dosage form tablets by rp-hplc using single mobile phase. International Journal of Applied Biology and Pharmaceutical Technology, 2010, 1(2): 683-688.

[96] Letica J, Markovic S, Zirojevic J, et al. High-Performance Liquid Chromatographic Determination of Pantoprazole and Its Main Impurities in Pharmaceuticals. Journal of AOAC International, 2010, 93(4): 1121-1128. https://doi.org/10.1093/jaoac/93.4.1121

[97] Hegazy MA, Yehia AM and Mostafa AA. StabilityIndicating Chromatographic Methods for Simultaneous Determination of Mosapride and Pantoprazole in Pharmaceutical Dosage Form and Plasma Samples. Chromatographia, 2011, 74: 839-845. https://doi.org/10.1007/s10337-011-2144-x

[98] Varsha J and Jitendra P. Simultaneous Estimation Of Cinitapride And Pantoprazole Sodium By Rp-Hplc In Their Marketed Formulation. International Journal of Chem Tech Research, 2012, 4(4): 1396-1401.

[99] Pandy S, Pandey P, Mishra D, et al. A validated stability indicating HPLC method for the determination of processrelated impurities in pantoprazole bulk drug and formulations. Brazilian Journal of Pharmaceutical Sciences, 2013, 49(1): 175-184. https://doi.org/10.1590/S1984-82502013000100019

[100] Erk N. Differential pulse anodic voltammetric determination of pantoprazole in pharmaceutical dosage forms and human plasma using glassy carbon electrode. Analytical Biochemistry, 2003, 323(1): 48-53. https://doi.org/10.1016/j.ab.2003.08.023

[101] Castro SL, Neto OD, Santos SR, et al. A flow-injection biamperometric method for determination of pantoprazole in pharmaceutical tablets. Journal of AOAC international, 2005, 88(4): 1064-1068. https://doi.org/10.1093/jaoac/88.4.1064

[102] Adegokea O, Umoha O and Soyinkab J. Spectrophotometric determination of metronidazole and tinidazole via charge transfer complexation using chloranilic acid. Journal of Iranian Chemical Society, 2010, 7(2): 359-370. https://doi.org/10.1007/BF03246021

[103] Kamel M, Barsoum B and Sayed R. Determination of some important antibacterial drugs using alizarins and thymol blue UV - Visible spectrophotometry. Journal of Applied Science, 2009, 5(7): 880-886.

[104] Nandipura D, Padmarajiah N and Kanchugar R. A Sensitive Spectrophotometric Assay for Tinidazole and Metronidazole Using a Pd-C and Formic Acid Reduction System. Turkish Journal of Chemistry, 2004, 28: 335-343.
[105] Nagaraja P, Sunitha K, Vasanta R, et al. Spectrophotometric determination of metronidazole and tinidazole in pharmaceutical preparations. Journal of Pharmceutical and biomedical Analysis, 2002, 28(3-4): 527-535. https://doi.org/10.1016/S0731-7085(01)00685-9

[106] Adegoke OA and Umoh OE. A new approach to the spectrophotometric determination of metronidazole and tinidazole using p-dimethylaminobenzaldehyde. Acta Pharmaceutica, 2009, 59(4): 407-419. https://doi.org/10.2478/v10007-009-0039-2

[107] Sinhg L and Nanda S. Method for Determination of Tinidazole using Direct UV-Visible Spectrophotometry and Differential Spectrophotometry in Pure and Tablet Dosage Forms. East and Central African Journal of Pharmaceutical Sciences, 2011, 14: 75-80.

[108] Abou-Taleb NH, El-Sherbiny DT, El-Wasseef DR, et al. Simultaneous determination of norfloxacin and tinidazole binary mixture by difference spectroscopy. International Journal of Biomedical Science, 2011, 7(2): 137-144.

[109] Alhemiary NA and Saleh MH. Spectrophotometric Determination of Tinidazole Using Promethazine and Ethyl Vanillin Reagents in Pharmaceutical Preparations. Der Pharma Chemica, 2012, 4(6): 2152-2160.

[110] Zheltvai OI, Zheltvai II, Spinul VV, et al. Spectrophotometry determination of metronidazole and tinidazole by their complexation with copper(II). Journal of Analytical Chemistry, 2013, 68(7): 600-605. https://doi.org/10.1134/S1061934813050171

[111] Sebaiy MM, Hassan WS and Elhennawy ME. Developing a High Performance Liquid Chromatography (HPLC) Method for Simultaneous Determination of Oxytetracycline, Tinidazole and Esomeprazole in Human Plasma. Journal of Chromatographic Sciences, 2019, 57(8): 724-729. https://doi.org/10.1093/chromsci/bmz046

[112] Sebaiy MM, Hassan WS, Saad MZ, et al. Developing a Highly Validated and Sensitive HPLC Method for Simultaneous Estimation of Oxytetracycline, Tinidazole and Esomeprazole in Their Dosage Forms. Austin Journal of Analytical and Pharmaceutical Chemistry, 2019, 6(1): 1112.

[113] Sebaiy MM, El-Shanawany AA, El-Adl SM, et al. Rapid RP-HPLC Method for Simultaneous Estimation of Norfloxacin and Tinidazole in Tablet Dosage Form. Asian Journal of Pharmaceutical Analysis. 2011, 1(4): 79-84.

[114] Sebaiy MM, El-Shanawany AA, El-Adl SM, et al. Rapid RP-HPLC Method for Simultaneous Estimation of Sparfloxacin, Gatifloxacin, Metronidazole and Tinidazole. Asian Journal of Pharmaceutical Research. 2011, 1(4): 119125.

[115] Pai PN, Rao GK, Srinivas B, et al. RPLC Determination of Tinidazole and Diloxanide Furoate in Tablets. Indian Journal of Pharmaceutical Sciences, 2008, 70(5): 670-672. https://doi.org/10.4103/0250-474X.45415

[116] Pasha K, Ali A, Bana S, et al. Reverse phase - HPLC method for the analysis of Tinidazole in pharmaceutical dosage form \& bulk drug. International Journal of Pharmacy and Pharmaceutical Sciences, 2010, 2(2): 46-47.

[117] Sneha JK, Nirav PB, Parag PR, et al. Development and validation of stability indicating method for simultaneous estimation of Ciprofloxacin hydrochloride and Tinidazole using RP-HPLC method. IOSR Journal of Pharmacy, 2012, 2(5): 
12-19. https://doi.org/10.9790/3013-25401219

[118] Kasnia V, Kumar MS and Mahadevan N. Simultaneous Estimation Of Amoxicillin, Tinidazole And Omeprazole In Microsphere Formulation By RP-HPLC. International Journal of recent Advances in Pharmaceutical Researches, 2012, 2(2): 78-83.

[119] Jiang XY, Chen XQ, Dong Z, et al. The application of resonance light scattering technique for the determination of tinidazole in drugs. Journal of Automated Methods and Management in Chemistry, 2007, Article ID 86857. https://doi.org/10.1155/2007/86857

[120] Alnajjar A, Abuseada HHnand Idris AM. Capillary electrophoresis for the determination of norfloxacin and tinidazole in pharmaceuticals with multi-response optimization. Talanta, 2007, 72(2): 824-846. https://doi.org/10.1016/j.talanta.2006.11.025

[121] Guzmán-Mar JL, Hinojoza-Reyes L, Hernandez-Ramirez A, et al. Automatic multisyringe flow injection system for the spectrophotometric determination of tinidazole in pharmaceutical preparations. Journal of the Chilean Chemical Society, 2010, 55(2): 215-218. https://doi.org/10.4067/S0717-97072010000200015

[122] Ramesh PJ, Basavaiah K and Rajendraprasad N. Sensitive and selective spectrophotometric assay of doxycycline hyclate in pharmaceuticals using Folin-Ciocalteu reagent. Acta Pharmaceutica, 2010, 60(4): 445-454. https://doi.org/10.2478/v10007-010-0032-9

[123] Rufino JL, Fernandes FC, Ruy MS, et al. A simple spectrophotometric method for the determination of tetracycline and doxycycline in pharmaceutical formulations using chloramine-t. Ecletica Quimica, 2010, 35(4): 139-146. https://doi.org/10.1590/S0100-46702010000400018

[124] Saber AL and Amin AS. Utility of Ion-Pair and Charge Transfer Complexation for Spectrophotometric Determination of Domperidone and Doxycycline in Bulk and Pharmaceutical Formulations. Journal of Analytical and Bioanalytical Techniques, 2011, 1: 113. https://doi.org/10.4172/2155-9872.1000113

[125] Li-Wei Z, Chong-Qiu J and Jing-Min S. Spectrofluorimetric determination of trace doxycycline with diethyl-O- $\beta$ cyclodextrin-doxycycline-Eu ${ }^{3+}$ system. Chinese Journal of Analytical Chemistry, 2008, 36(11): 1547-1550.

[126] Attia MS, Mahmoud WH, Ramsis MN, et al. Spectrofluorimetric assessment of doxycycline hydrochloride in pharmaceutical tablets and serum sample based on the enhancement of the luminescence intensity of the optical sensor $\mathrm{Sm}^{3+}$ ion. Journal of Fluorescence, 2011, 21(4): 1739-1748. https://doi.org/10.1007/s10895-011-0869-4

[127] Axisa B, Naylor AR and Bell PR, Thompson M. Simple and reliable method of doxycycline determination in human plasma and biological tissues. Journal of Chromatography B: Biomedical Sciences and Applications, 2000, 744(2): 359-365. https://doi.org/10.1016/S0378-4347(00)00261-9
[128] Zarghi A, Kebriaeezadeh A and Ahmadkaniha R. Rapid high-performance liquid chromatographic method for determination of doxycycline in human plasma. Bollettino Chimico Farmaceutico, 2001, 140(2): 112-114.

[129] Ruz N, Zabala M, Kramer M, et al. Rapid and simple determination of doxycycline in serum by high-performance liquid chromatography - Application to particulate drug delivery systems. Journal of Chromatography A, 2004, 1031(12): $295-301$.

https://doi.org/10.1016/j.chroma.2003.12.028

[130] Skulason S, Ingolfsson E and Kristmundsdottir T. Development of a simple HPLC method for separation of doxycycline and its degradation products. Journal of Pharmaceutical and Biomedical Analysis, 2003, 33(4): 667-672. https://doi.org/10.1016/S0731-7085(03)00316-9

[131] Injac R, Djordjevic-Milic V and Srdjenovic B. Thermostability Testing and Degradation Profiles of Doxycycline in Bulk, Tablets, and Capsules by HPLC. Journal of Chromatographic Science, 2007, 45: 623-628. https://doi.org/10.1093/chromsci/45.9.623

[132] Mitic SS, Miletic GZ, Kostic DA, et al. A rapid and reliable determination of doxycycline hyclate by HPLC with UV detection in pharmaceutical samples. Journal of the Serbian Chemical Society, 2008, 73(6): 665-671. https://doi.org/10.2298/JSC0806665M

[133] Krishna AC, Sathiyaraj M, Saravanan RS, et al. A novel and rapid method to determine doxycycline in human plasma by liquid chromatography tandem mass spectrometry. Indian Journal of Pharmaceutical Sciences, 2012, 741(6): 541-548. https://doi.org/10.4103/0250-474X.110599

[134] Sulaiman ST and Abdul Razzak FH. Differential- Pulse Polarographic Determination of Doxycycline in Serum and Urine. Rafedain Journal Sciences, 2008, 19(1): 52-58.

[135] Al-Momani IF and Kanan SJ. Flow-Injection spectrophotometric and LC determination of doxycycline, oxytetracycline and chlortetracycline in biological fluids and pharmaceutical preparations. Journal of Flow Injection Analysis, 2008, 25(1): 29-34.

[136] Rufino JL, Weinert PL, Pezza HR, et al. Flow-injection spectrophotometric determination of tetracycline and doxycycline in pharmaceutical formulations using chloramine-T as oxidizing agent. Quimica Nova, 2009, 32(7): 1764-1769. https://doi.org/10.1590/S0100-40422009000700016

[137] Issa YM, Abdel-Fattah HM and Abdel-Moniem NB. Chemically Modified Carbon Paste Sensor for Potentiometric Determination of Doxycycline Hydrochloride in Batch and FIA Conditions. International Journal of Electrochemical Science, 2013, 8: 9578-9592.

[138] Gurler B, Ozkorucuklu SP and Kir E. Voltammetric behavior and determination of doxycycline in pharmaceuticals at molecularly imprinted and non-imprinted overoxidized polypyrrole electrodes. Journal of Pharmaceutical and Biomedical Analysis, 2013, 84: 263-268. https://doi.org/10.1016/j.jpba.2013.06.009 